\title{
ALUR KERJA BARU SIMULASI PERFORMA BANGUNAN DALAM PROSES DESAIN PARAMETRIK
}

\author{
Firza Utama Sjarifudin \\ Jurusan Arsitektur, Fakultas Sains dan Teknologi, Bina Nusantara University \\ Jln. KH Syahdan No 9, Palmerah, Jakarta Barat 11480 \\ firza.utama@binus.ac.id
}

\begin{abstract}
Makalah ini menjelaskan hubungan alur kerja baru antara program pemodelan CAD $3 D$ (Rhino/Grasshopper) dan simulasi pencahayaan dengan (Radiance/Daysim). Alur kerja perancangan yang sangat efektif dalam Rhino disajikan secara langsung dengan mengekspor geometri, material properties, dan sensor grid ke dalam format Radiance/Daysim untuk menghitung serangkaian indikator performa termasuk peta radiasi matahari serta faktor pendistribusian pencahayaan dalam setahun. Hasil simulasi secara otomatis dikirim kembali ke dalam Rhino menggunakan pemetaan warna. Dengan menggunakan Grasshopper, parameter desain utama seperti ukuran jendela dan deskripsi material dapat diubah secara bertahap dan hasil simulasi dapat dikombinasikan menjadi sebuah simulasi performa bangunan dalam bentuk animasi transformasi parametrik. Desain alur kerja ini telah secara khusus dikembangkan bagi proses perancangan arsitektur dengan menyediakan semua feedback yang sangat berguna bagi perancang secara interaktif dari tahap rancangan skematis sampai tahap pengembangan perancangan.
\end{abstract}

Kata kunci: simulasi pencahayaan alami, desain parametrik, performa bangunan

\begin{abstract}
ABSTRAK
This paper describes the new workflow relationship between the $3 D$ CAD Modeler (Rhino/Grasshopper) and lighting simulation (Radiance/Daysim). A very effective design workflow in Rhino presented directly by exporting geometry, material properties, and sensor grids into Radiance/Daysim format to calculate a set of performance indicators including solar radiation maps and daylight distribution factors in a year. The simulation results are automatically sent back to the Rhino using color mapping. By using Grasshopper, the main design parameters such as window size and description of materials can be changed gradually and the simulation results can be combined into a building performance simulation in the form of parametric transformation animation. The Workflow has been specifically developed for the architectural design process by providing all the interactive feedback that is very useful for a designer from the schematic design phase until the design development stage.
\end{abstract}

Keywords: daylight simulation, parametric design, building performance 


\section{PENDAHULUAN}

Desain Parametrik telah menjadi alat bantu yang semakin banyak digunakan dalam praktek desain arsitektur dan pendidikan kontemporer (Day, 2010). Istilah desain parametrik ini mengacu pada praktek pemodelan digital dari serangkaian varian desain yang mempunyai hubungan antara satu sama lain dan ditentukan melalui satu atau beberapa hubungan matematis (parameter) yang kemudian membentuk ruang parametrik terdiri dari puluhan atau ribuan bentuk yang saling berhubungan namun berbeda secara geometris. Serangkaian contoh bentuk-bentuk yang dihasilkan dari desain parametrik dapat dilihat dalam Gambar 1.

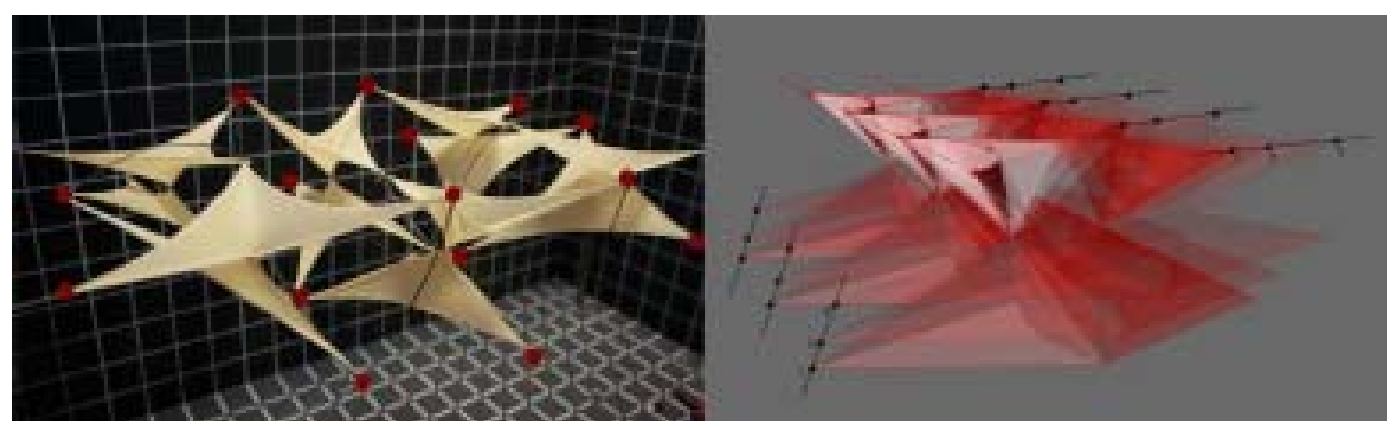

Gambar 1 Contoh studi desain parametrik menggunakan Rhino/Grasshopper: Suatu hubungan antar komponen bentuk di mana titik menghasilkan garis yang kemudian menghasilkan permukaan. Perubahan pada posisi titik menghasilkan beragam bentuk dalam dua dan tiga dimensi

Sejauh ini, desain parametrik telah digunakan sebagian besar untuk eksplorasi estetika yang menekankan pada segi kompleksitas dan alternatif perubahan bentuk secara menerus. Aspek perancangan berbasis performa yang sudah banyak dilakukan adalah rasio luas lantai dan batasanbatasan lain yang ditentukan oleh topografi perkotaan pada tapak bangunan. Dengan meningkatnya fokus masyarakat pada efisiensi energi dan kenyamanan pengguna bangunan sekarang ini, menyebabkan timbulnya kebutuhan yang berkembang dalam bidang desain parametrik untuk memasukkan unsur aspek performa yang terkait dengan sustainability, terutama dari segi energi dan pencahayaan alami. Simulasi pencahayaan telah digunakan selama beberapa dekade dan mulai banyak metode pada analisis perancangan dengan cara mengubah geometri dan definisi material dari berbagai jenis CAD modeler ke dalam paket-paket simulasi pencahayaan. Pada urutan peringkat yang teradapat dalam sistem Green Building seperti sistem LEED US Green Building Council (USGBC 2009) mendorong penggunaan simulasi, tidak mengherankan bahwa praktisi desain semakin banyak menyatakan bahwa mereka telah menggunakan simulasi pencahayaan dalam perusahaan mereka (Galasiu \& Reinhart, 2009).

Pada kebanyakan alur kerja analisa pencahayaan alami melibatkan beberapa langkah yaitu (1) mengekspor file geometri ke dalam format file sementara; (2) mengimpor file ke dalam sebuah program analisis cahaya matahari; (3) mengatur sifat material dan parameter simulasi; (4) menjalankan simulasi; (5) mengimpor hasil kembali ke program CAD untuk visualisasi data. Alur kerja seperti ini terlihat cukup menyulitkan dan panjang bagi pengguna umum yang hanya ingin melakukan uji coba secara cepat untuk menilai seberapa baik performa desain mereka pada saat tertentu. Langkah-langkah manual tersebut biasanya menimbulkan hambatan bagi perancang yang berkeinginan untuk menghasilkan sejumlah besar variasi desain secara otomatis.

Makalah ini menyajikan alur kerja baru penganalisaan pencahayaan alami dengan menggunakan Radiance/Daysim dalam lingkungan pemodelan CAD dengan menggunakan 
Rhino/Grasshopper Untuk mengatasi hambatan tersebut diatas. Makalah ini juga mengeksplorasi cara baru memvisualisasikan hasil dari simulasi pencahayaan alami untuk sejumlah besar iterasi desain yang menghasilkan hasil signifikan dan dapat menunjukkan keunggulan didalamnya, sehingga dapat membantu perancang untuk menghasilkan nilai-nilai dalam proses perancangan parametrik.

Sebelum meninjau rincian alur kerja baru tersebut, selanjutnya akan dilihat apakah sebenarnya ada kebutuhan akan alur kerja baru yang lebih baik dari alur kerja biasa dalam melakukan analisis seperti melalui ekspor dari Rhino dan ECOTECT ke dalam Radiance/Daysim. Pada pengamatan dari perkembangan yang ada terlihat bahwa sudah ada kecenderungan paling tidak dalam pendidikan arsitektur dimana siswa dibebani oleh banyak alat software yang dapat mengurangi produktifitas. Selain itu dari segi interoperability (kemampuan banyak sistem untuk bekerja dalam satu pekerjaan) menjadi sumber kesalahan yang signifikan dalam melakukan simulasi terutama bagi pemula (Ibarra \& Reinhart 2009). Dari kondisi ini dapat dinilai bahwa model alur kerja pengoperasian dalam satu software environment akan sangat bermanfaat.

Tujuan dari makalah ini adalah untuk menciptakan sebuah model alur kerja yang: (1) dapat difungsikan dengan metode pemodelan yang sudah ada; 2) menggunakan mesin simulasi dapat diandalkan; (3) menghasilkan produk visualisasi yang berguna. Hasil dari makalah ini adalah sebuah model alur kerja baru yang dapat mengubah parameter desain seperti ukuran jendela dan menghitung performa kinerja pencahayaan yang pada akhirnya menggabungkan semua ke dalam Simulasi Performa Bangunan dalam bentuk animasi. Alur kerja itu sendiri akan dijelaskan dalam bagian Metode Penelitian diikuti oleh sebuah contoh aplikasinya. Pada bagian Hasil dan Pembahasan akan menjelaskan kemungkinan-kemungkinan yang dapat dihasilkan dari penerapan alur kerja ini dalam praktek perancangan.

\section{METODE}

Rhino merupakan salah satu program CAD yang banyak digunakan dalam industri desain karena kemudahan penggunaan dan kecepatan dalam pemrosesan. Grasshopper yang merupakan plugin dari Rhino adalah sebuah editor algoritma grafis yang memungkinkan pengguna tanpa pengalaman membuat programming script untuk menghasilkan bentuk-bentuk parametrik (Day, 2010). Penggunaan Rhinoceros dan Grasshopper untuk pengembangan alur kerja dalam makalah ini dilatar belakangi dari popularitas penggunaan software tersebut baik dalam lingkungan pemodelan tradisional maupun parametrik serta digunakan secara luas baik di kalangan mahasiswa maupun profesional. Selain itu, sampai saat makalah ini dibuat, belum ada paket software lain yang menyediakan komponen yang diperlukan untuk pembuatan alur kerja yang baik kecuali dalam Rhino dan Grasshopper.Alur kerja pada makalah ini dibedakan menjadi dua jenis simulasi, yaitu (1) analisa varian tunggal, yang mengacu pada simulasi performa pencahayaan alami terhadap salah satu varian desain pada waktu tertentu; (2) analisa varian majemuk, yang mengacu pada serangkaian simulasi variasi desain berdasarkan pada perubahan parameter.

Seperti yang telah dijelaskan diatas, model yang dihasilkan oleh Rhino/Grasshopper dapat digunakan untuk berbagai bentuk Analisa pencahayaan alami varian tunggal dengan menggunakan plug-in renderer yang dapat menghasilkan studi bayangan secara langsung atau dengan mengekspor file ke dalam software lain untuk analisa lebih lanjut. Kelemahan dari penggunaan plug-in renderer ini adalah bahwa simulasi yang dihasilkan terkonsentrasi pada jenis paling mendasar dari analisa pencahayaan (hasil render dari simulasi pencahayaan yang didapat tidak menggunakan data kondisi iklim lokal) atau dibatasi pada visualisasi tanpa analisis kuantitatif (plug-in VRay). 
Saat ini terdapat kecenderungan dalam analisis pencahayaan alami dengan pendekatan yang lebih mutakhir, pengevaluasian desain holistik berbasis iklim dan waktu (Reinhart, 2006). Seperti yang sudah disampaikan sebelum ini, dalam menganalisa pencahayaan alami untuk varian majemuk diperlukan langkah-langkah dalam alur kerja yang luas dan penggunaan beberapa program untuk mendapatkan hasil yang dapat diandalkan. Dengan kemampuan pemodelan parametrik untuk menghasilkan iterasi desain dalam jumlah besar dengan cepat, akan sangat sulit untuk melakukan analisa pencahayaan dengan jumlah sebanyak yang dihasilkan dari iterasi desain jika menggunakan alur kerja tradisional.

Alur kerja baru yang ditawarkan terdiri dari tiga bagian utama: 1) Rhino toolbar, 2) File Grasshopper, 3) Radiance/Daysim engine (Gambar 2). Untuk analisa varian tunggal Rhino toolbar dapat digunakan tanpa Grasshopper sedangkan untuk melakukan analisa varian majemuk perlu menggunakan komponen Grasshopper. Radiance/Daysim digunakan sebagai engine penghitung performa.

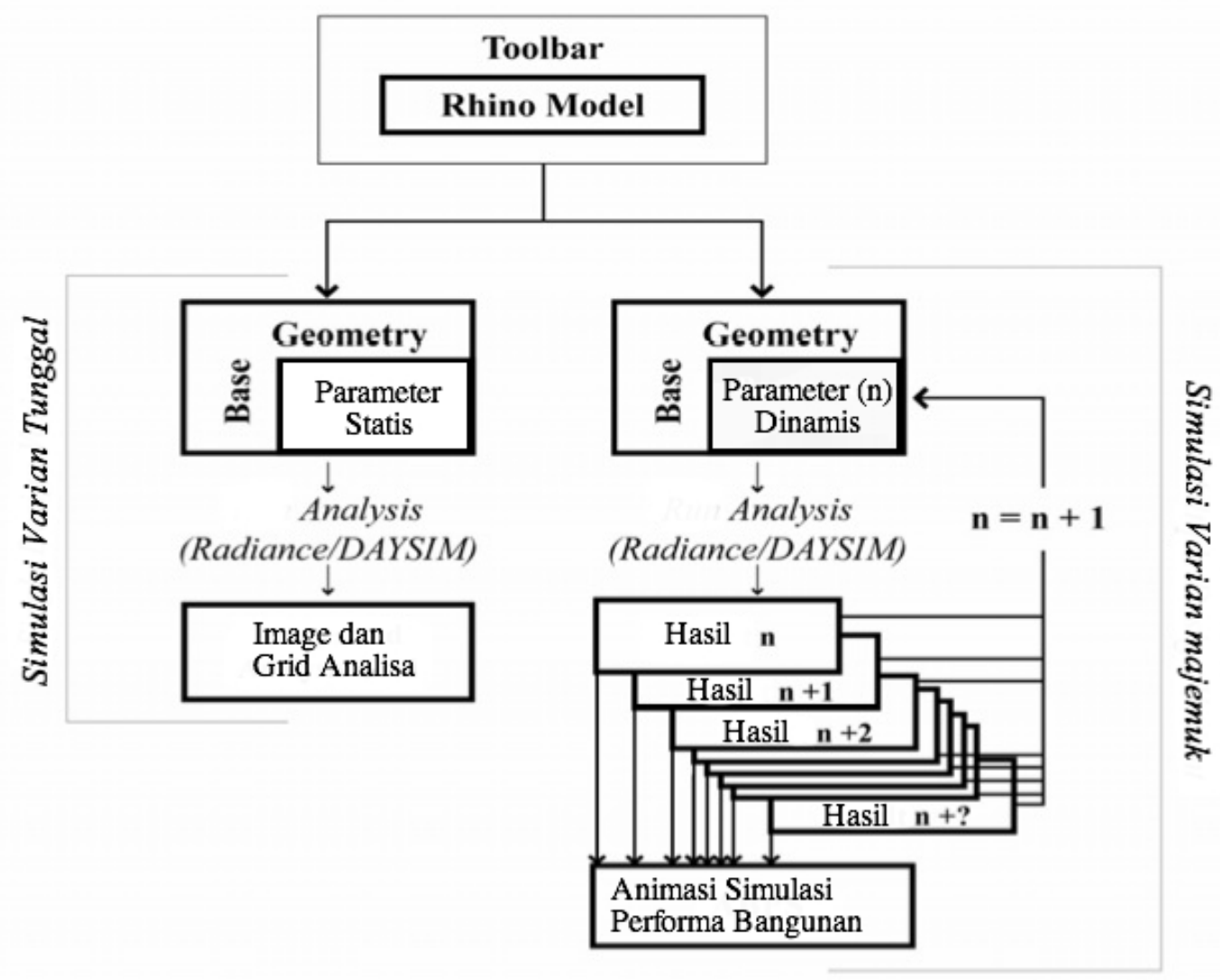

Gambar . Alur kerja SPB (Simulasi Performa Bangunan)

\section{Rhino Toolbar}

Rhino toolbar merupakan kumpulan command icon yang diprogram dalam RhinoScript untuk melakukan setup dan menjalankan simulasi pencahayaan alami, toolbar ini digunakan bersamaan dengan model yang dibuat di dalam Rhino yang terdiri dari empat icon: Project Info, Nodes, Materials, dan Metrics. Icon Project Info berfungsi untuk menetapkan penamaan file, lokasi penyimpanan, dan lokasi geografis proyek. Icon Nodes berfungsi untuk menempatkan serangkaian titik sensor yang tersusun pada surface geometry untuk menentukan area yang diperlukan dalam 
penganalisaan performa. Icon Materials berfungsi untuk menetapkan material standar dari Radiance ke dalam bentuk layers. Icon Metrics menyediakan empat pilihan percobaan untuk dijalankan pada model yang diberikan: Image, Radiation Maps, Daylight Factor, Climate-Based Metrics (Kondisi pencahayaan alami dan iluminasi).

Percobaan Image menghasilkan gambar render dari Radiance (Gambar 3). Percobaan Radiation Maps menghasilkan peta radiasi matahari dalam format HDR Radiance (Gambar 4). Percobaan Daylight Factor dan Climate-Based Metrics menghasilkan panel-panel grid warna dalam Rhino yang didasarkan pada data data titik sensor simulasi dan lokasi (Gambar 5 dan 6). Pada Rhino toolbar ini terdapat beberapa batasan dalam penggunaannya yaitu pada versi ini tidak dimungkinkan untuk memproses mesh geometry, dan tidak mensupport pembuatan titik sensor grid berdasarkan permukaan non-horizontal atau non-vertikal. Keterbatasan tersebut diharapkan dapat diperbaiki dalam versi-versi yang lebih baru.

\section{Grasshopper Editor}

Plug-in Grasshopper berfungsi untuk menghubungkan bagian-bagian tertentu dari geometri yang dibuat dalam Rhino atau dapat juga berfungsi sebagai editor grafis algoritma. preview dari geometri tersebut dapat terlihat dalam viewport Rhino, hasil transformasi geometri dari perubahan algoritma yang dilakukan pada editor grafik akan ter-update secara langsung. Salah satu komponen yang paling intuitif dalam editor Grasshopper adalah slider. Pengoperasian slider adalah dengan menggeser sepanjang rentang nilai numerik dan akan mendapatkan feedback visual secara langsung dari efek geometrik dari perubahan parameter. Fungsi animasi juga terdapat dalam slider yang memungkinkan pengguna untuk mengatur lebih jauh sejumlah iterasi desain. Iterasi visual ini disimpan sebagai image viewport dan dapat dikompilasikan menjadi sebuah animasi.

Untuk dapat menggunakan Grasshopper dalam file yang mengandung geometri dalam bentuk statis dan dinamis diperlukan dua langkah proses. Pertama, setting dari Nodes, Materials, dan Radiance ditetapkan melalui Rhino toolbar seperti yang dijelaskan diatas. Selanjutnya, bagian dari geometri model dan algoritma geometri dibuat dalam Grasshopper dalam bentuk dinamis. Transformasi parametrik dari geometri tersebut kemudian dapat ditentukan dan slider dalam Grasshopper difungsikan untuk menganimasikan perubahan yang terjadi. Algoritma yang dibuat dalam Grasshopper tersebut kemudian menjalankan file dengan parameter simulasi Radiance dan pilihan pencahayaan menggunakan toolbar. Hasil simulasi tersebut dapat dilihat dalam Render Viewport dalam Rhino, dan hasil data model geomatri tersebut ditampilkan dalam bentuk gradasi warna. Dengan menganimasikan slider akan mengirim urutan transformasi geometri yang secara berurutan masing-masing menjalankan update simulasi Radiance. Hasilnya kemudian disimpan sebagai rangkaian image viewport yang kemudian disusun menjadi sebuah animasi.

\section{Radiance/Daysim Engine}

Alur kerja berikut ini menggunakan raytracer Radiance untuk menghitung faktor distribusi pencahayaan (Gambar 5) dan visualisasi model (Gambar 3) dalam kondisi langit cerah (Ward \& Shakespeare 1998) dan (Mardaljevic, 1995). Untuk simulasi pencahayaan climate-based digunakan alur kerja Radiance berbasis Daysim untuk menghitung ketersediaan pencahayaan alami (Gambar 6) yang berbasis pada rangakaian sensor dalam grid (Reinhart \& Walkenhorst 2001). Untuk perhitungan pemetaan radiasi per tahun digunakan metode GenCumulativeSky (Robinson \& Stone 2004).

\section{Studi Kasus}

Untuk mendemonstrasikan penggunaan dan hasil dari Simulasi Performa Bangunan, dibuat studi kasus dengan mengambil objek bangunan Sekolah Manajemen dan Desain Zollverein di Essen, 
dirancang oleh SANAA (Sejima, et.al., 2008). Secara khusus bangunan ini dipilih karena geometri bangunan sangat sesuai dan memungkinkan untuk mendapatkan tampilan yang jelas dari parameter berbagai elemen seperti skylight, jendela dan bentuk secara keseluruhan.

\section{Hasil Varian Tunggal}

Gambar 4-7 memperlihatkan empat hasil percobaan varian tunggal menggunakan Metrics yang dihasilkan dari Rhino toolbar tanpa adanya animasi. Gambar 3 memperlihatkan visualisasi Radiance bangunan dengan konidisi langit mendung. Pada langkah pertama dalam alur kerja ini disarankan untuk menjalankan visualisasi Radiance yang bertujuan untuk mengontrol kualitas simulasi dengan memastikan bahwa semua elemen untuk simulasi telah terekspor dengan benar dari Rhino ke dalam Radiance.

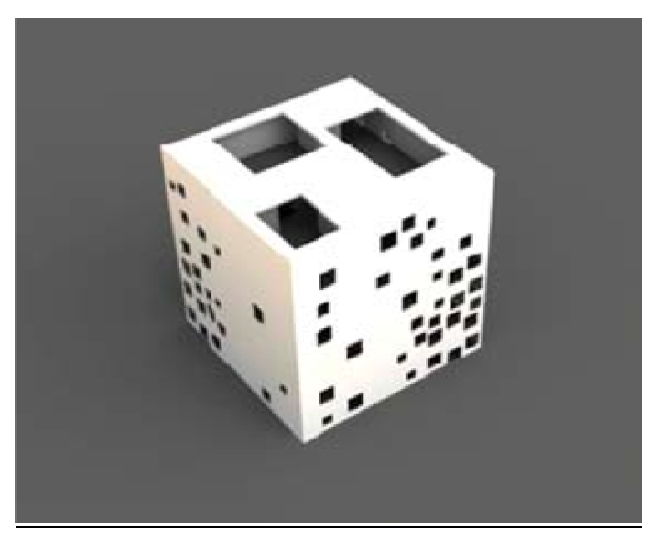

Gambar 3 Hasil varian tunggal: Image.

Gambar 4 memperlihatkan peta radiasi tahunan pada bangunan menggunakan file data iklim pada lokasi bangunan tersebut. Pada gambar tersebut menunjukkan radiasi matahari tahunan yang mengenai bidang permukaan bangunan diasosiasikan dengan grid piksel dalam gambar, sebagai contoh sedikit diatas $1000 \mathrm{kWh} / \mathrm{m} 2$ mengenai permukaan atap. Jenis data semacam ini dapat digunakan untuk analisa perancangan lebih lanjut dari tingkat bangunan sampai tingkat perkotaan.

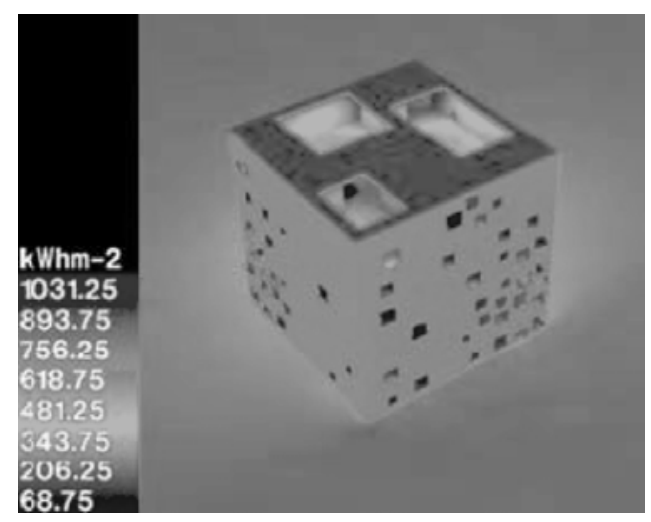

Gambar 4. Hasil varian tunggal: Radiation Map

Gambar 5 memperlihatkan distribusi faktor pencahayaan alami pada lantai atas bangunan yang mengungkapkan bahwa cukup banyak cahaya pada lantai tersebut dikarenakan adanya beberapa skylight. 
Gambar 7 memperlihatkan kondisi distribusi pencahayaan alami pada lantai atas bangunan. Kondisi cahaya alami merupakan gabungan dari percobaan climate-based metrics yang menangkap supply atau oversupply dari cahaya alami dalam satu nilai angka (Reinhart \& Walkenhorst, 2001). Dengan asumsi bahwa target iluminasi dalam bangunan adalah 500 lux dan waktu penggunaan aktif bangunan adalah pada hari kerja jam 9:00-17:00, angka menunjukkan persentase waktu penggunaan bangunan ketika paling sedikit 500 lux didapat dari cahaya alami. Kode warna digunakan dari biru (rendah) sampai hijau (tinggi) dan mencapai saturasi ketika cahaya alami mencapai suatu titik minimal $50 \%$ dari nilai maksimum dalam model. Area dengan warna hijau menandakan area cahaya alami sedangkan warna biru menandakan area dimana terdapat kurang cahaya alami. Pada akhirnya, percobaan dilakukan untuk mengetahui berapa banyaknya iluminasi pada suatu titik lebih dari 10 kali nilai target 500 lux. Jika hal tersebut terjadi lebih dari 5\% dari waktu penggunaan bangunan maka pada titik tersebut terjadi kelebihan cahaya dan pada area tersebut akan berubah menjadi warna merah. Gambar 8 menunjukkan bahwa tiga skylight besar yang terdapat pada bangunan menyebabkan terlalu banyaknya cahaya pada lantai atas, dan dapat diasumsikan bahwa aktifitas perkantoran dilakukan pada lantai tersebut dan tidak adanya penghalang sinar yang disediakan.

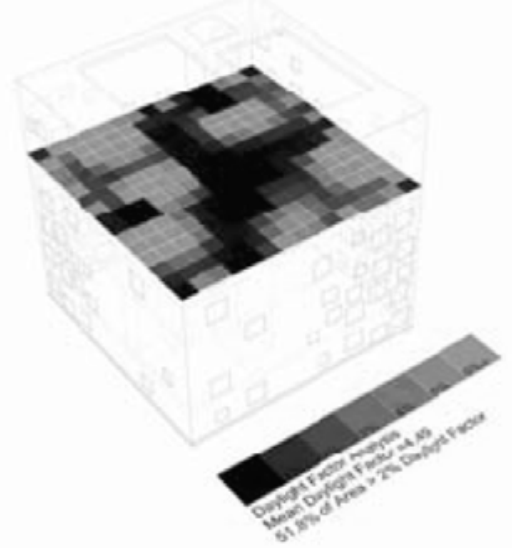

Gambar 5. Hasil varian tunggal: Daylight Factor.

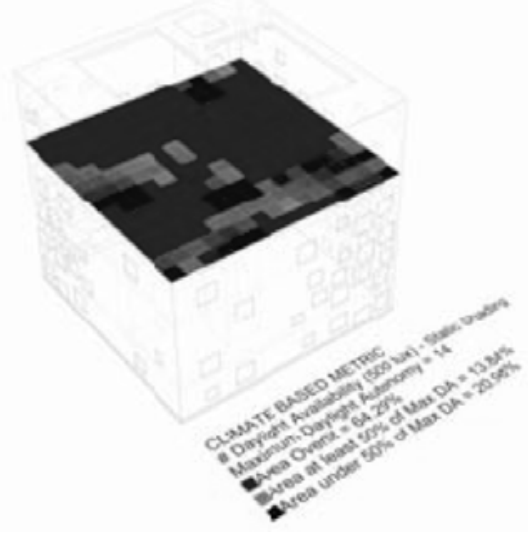

Gambar 6. Hasil varian tunggal: Daylight Availability

\section{Hasil Varian Majemuk}

Dengan menambahkan unsur transformasi parametrik akan menghasilkan beberapa varian dan hasil akhir yang dapat diperoleh adalah sebuah simulasi animasi. Gambar 7 memperlihatkan potonganpotongan dari animasi yang didapat. Animasi tersebut menunjukkan efek dari berbagai macam konfigurasi skylight dan jendela yang mempengaruhi kondisi pencahayaan pada keseluruhan lima lantai dari bangunan.
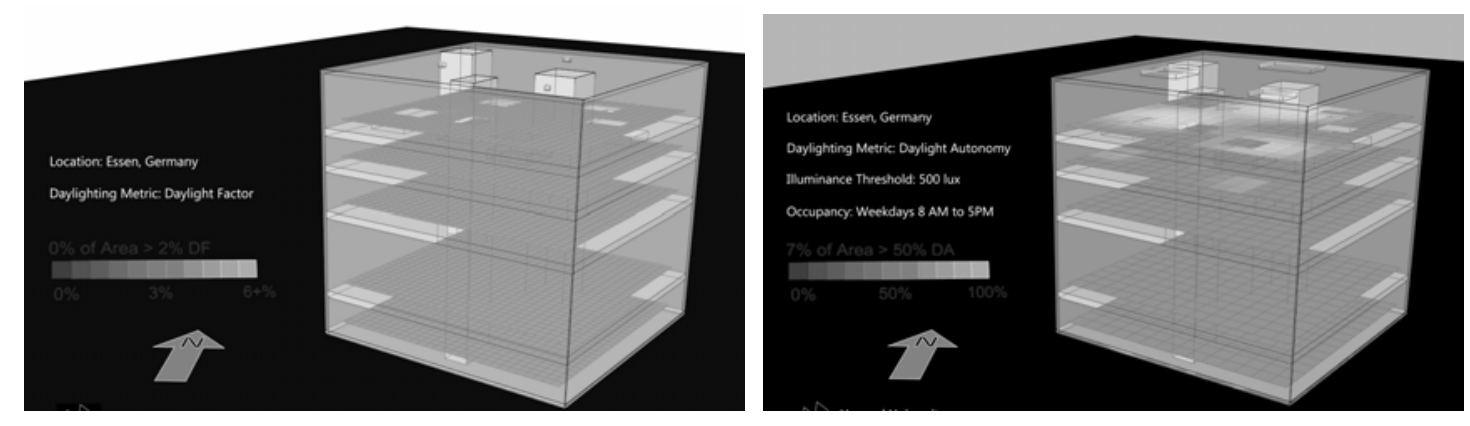

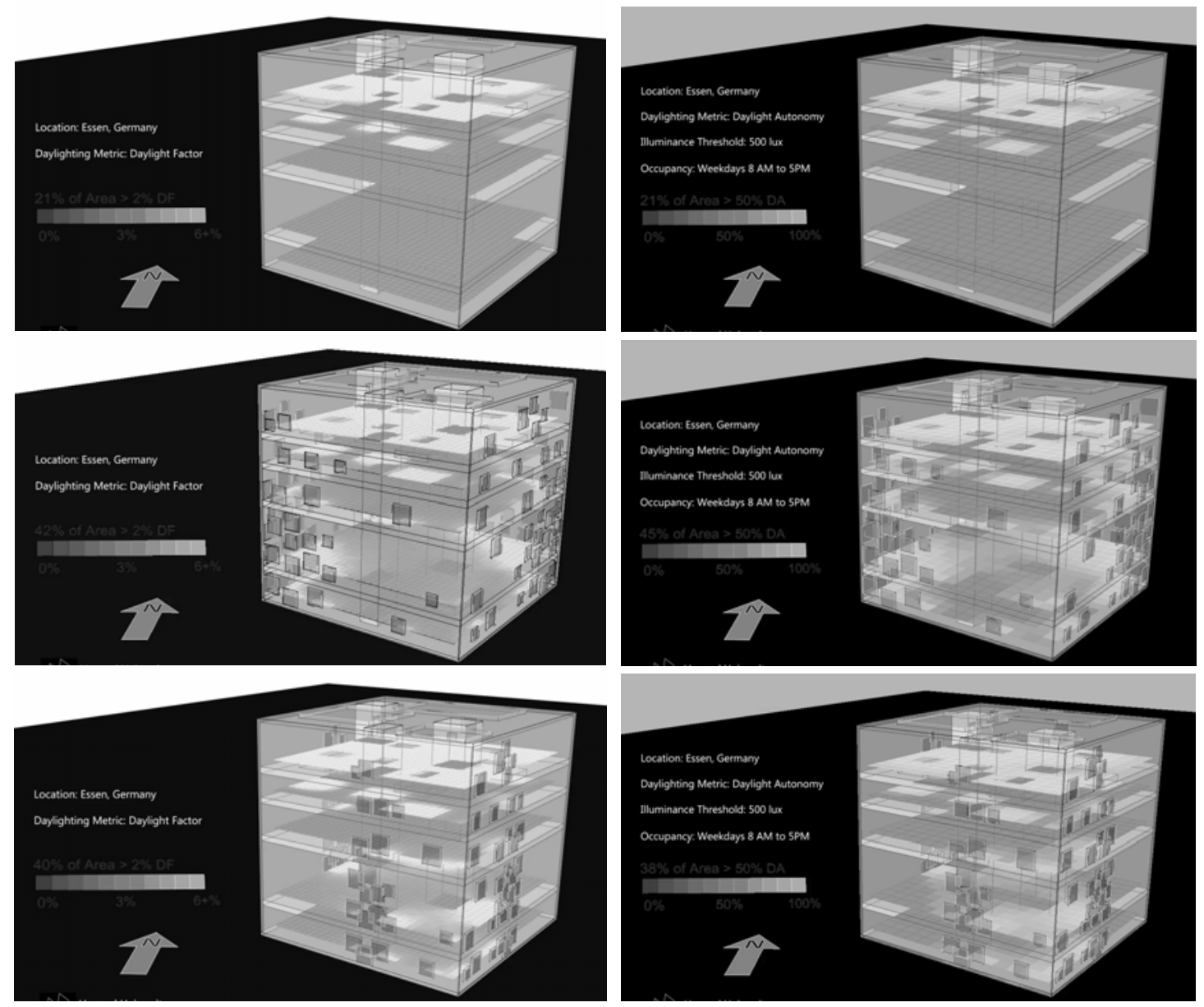

Gambar 7. Hasil varian majemuk: potongan dari hasil animasi simulasi performa bangunan. Pada lajur kiri memperlihatkan hasil dari simulasi Daylight Factor. Pada lajur kanan memperlihatkan hasil dari simulasi Daylight Autonomy.

\section{PEMBAHASAN}

\section{Analisa Awal}

Penerapan lain yang menarik untuk topik ini adalah dalam penghitungan performa pada tahap awal perancangan untuk penentuan tapak, dimana perubahan-perubahan masih lebih mudah untuk dilakukan. Dikarenakan hambatan dalam penggunaan alur kerja yang sudah ada sering mengakibatkan dikesampingkannya pembuatan simulasi lingkungan dalam proses perancangan (Galasiu \& Reinhart, 2007). Oleh karena itu sangat dibutuhkan adanya alat bantu simulasi pencahayaan yang mudah dalam penggunaannya dan dapat menghasilkan umpan balik yang cepat sehingga dapat menjadi suatu hal yang ideal untuk dilakukan pada tahap awal proses perancangan ketika keputusan yang paling mempengaruhi biasanya dibuat dimana paling banyak dipengaruhi oleh faktor pencahayaan alami. Sebagai alat bantu yang fleksibel seharusnya tidak hanya terbatas untuk analisa awal akan tetapi kedepannya dapat pula dimungkinkan untuk diterapkan pada rancangan skematis sampai pengembangan desain. 


\section{Otomatisasi}

Dari alur kerja dan alat bantu analisa parametrik lain yang disampaikan pada makalah ini akan dapat menimbulkan perdebatan apakah evaluasi perancangan berdasarkan dari analisis parametrik akan menghasilkan suatu 'otomatisasi perancangan'. Tanggapan akan hal tersebut adalah pada kenyataannya dengan penambahan simulasi performa bangunan dalam proses desain parametrik sama sekali tidak menyiratkan bahwa harus ada solusi tunggal, melainkan solusi performa yang ideal akan dapat dihasilkan dari berbagai pertimbangan yang banyak dilakukan sebelumnya oleh perancang dan juga pada pengaplikasian tahap-tahap yang berbeda akan menghasilkan keputusan desain yang berbeda. Sebagai contoh, beberapa perancang mungkin cenderung untuk menggunakan simulasi performa bangunan dalam pengeksplorasian bentuk dalam tahap perancangan mereka, atau ada juga yang menggunakannya untuk memahami bagaimana bentuk bangunan bereaksi terhadap suatu kondisi tertentu.

\section{SIMPULAN}

Dengan menyederhanakan proses analisa performa bangunan, dapat dihasilkan peningkatan kecepatan bersamaan dengan output simulasi yang lebih dapat diandalkan, selain itu dapat pula menghasilkan visualisasi yang komprehensif dalam bentuk animasi. Alur kerja yang disampaikan pada makalah ini berkontribusi pada peningkatan kemampuan perancang di berbagai tahap perancangan untuk melakukan analisa pencahayaan alami yang berguna. Alur kerja ini juga mempermudah pengoperasian antar desain dan analisa lingkungan, dengan menyatukan alur kerja analisa ke dalam Rhino dapat mengurangi hambatan dalam penggunaan alat secara signifikan.

Dengan melihat implikasi dari alur kerja ini pada efisiensi dan efektifitas proses perancangan, pada pengembangan selanjutnya akan dapat menjadi pendorong menuju pemproduksian alat-alat yang mampu menyatukan proses desain parametrik dengan simulasi performa bangunan.

\section{DAFTAR PUSTAKA}

Day, M. (2000-2010). Rhino Grasshopper. AEC Magazine, X3DMedia, from http://aecmag.com.

Galasiu, A., \& Reinhart, C. F. (2007). Current Daylighting Design Practice: A Survey. Building Research and Information, 36(2): 159- 174.

Ibarra, D., \& Reinhart, C. F. (2009). Daylight factor simulations - 'How close do simulation beginners 'really' get. Proceedings of Building Simulation 2009, Glasgow, Scotland.

Mardaljevic, J. (1995). Validation of a Lighting Simulation Program under Real Sky Conditions. Lighting Research \& Technology, 27(4): 181-188.

Reinhart, C. F., \& Walkenhorst, O. (2001). Dynamic RADIANCE-Based Daylight Simulations for a Full-Scale Test Office with Outer Venetian Blinds. Energy \& Buildings, 33(7): 683-697.

Robinson, D., \& Stone, A. (2004). Irradiation Modeling Made Simple: the Cumulative Sky Approach and Its Applications. PLEA Conference 2004, 19-22 September 2004: 1-5, Eindhoven, The Netherlands. 
Sejima, K., Nishizawa, R., \& Cortes, J. A. (2008). SANAA Kazuyo Sejima, Ryue Nishizawa 20042008. Croquis no.139, Madrid, Spain.

Ward, G., \& Shakespeare, R. (1998). Rendering with RADIANCE, The Art and Science of Lighting Visualization. San Francisco, CA, USA: Morgan Kaufmann Publishers. 